\title{
SPECTRUM OF Tp53 GENE MUTATION IN BASAL CELL CARCINOMA AND ITS MORPHOLOGICAL SUBTYPES IN PEOPLE OF COLOR.
}

\footnotetext{
1. M.Phil Pathology Assistant Professor Department of Pathology Sindh Medical College, Jinnah Sindh Medical University, Karachi, Pakistan.

2. M.Phil Pathology Professor Department of Pathology Basic Medical Sciences Institute Jinnah Post Graduate Medical Center, Karachi, Pakistan.

3. M.Phil Pathology Assistant Professor Department of Pathology Muhammad Medical College, Mirpur Khas, Pakistan.

4. PhD.

Professor

Department of Pathology Sindh Medical College, Jinnah Sindh Medical University, Karachi, Pakistan.

5. Final Year MBBS Student Jinnah Sindh Medical University.

Correspondence Address:

Dr. Nazish Jaffar

Pathology Department, Sindh Medical

College, Jinnah Sindh Medical

University, Rafiqui Shaheed Road, Karach

drnazishamin@gmail.com
}

Article received on:

04/09/2018

Accepted for publication:

15/03/2019

Received after proof reading:

$30 / 09 / 2019$
Nazish Jaffar', Shahnaz Imdad Kehar², Aliya Zaman³, Saadia Akram, Kiran Abbas ${ }^{5}$

ABSTRACT... Objectives: Basal cell carcinoma (BCC) is the most common cutaneous malignancy in white population. The pattern of exon specific p53 mutations in BCC and its subtypes remain undetected in our population. This study was designed to evaluate the prevalence and mutational spectrum of p53 mutations in basal cell carcinoma (BCC) and its subtypes in people of color in the population of Karachi, Pakistan. Study Design: Retrospective cross sectional study. Setting: Department of Pathology, Basic Medical Sciences Institute, Jinnah Post Graduate Medical Center Karachi, Pakistan. Period: Five-year study from January 2012 to December 2016. Material and Methods: Convenient sampling technique was used. Sample size was calculated using open EPI software. Analysis of 32 BCC cases for p53 gene mutations in exons 5-8 was detected by polymerase chain reaction technique. Sebaceous carcinoma and malignant melanoma were used as positive controls and normal skin was used as negative control. Results: Out of 32 BCC cases, 26 (81.2\%) displayed p53 exon mutations. The number of cases with single exon mutation was 17 (65.3\%). Exon 5 mutation was most frequently observed in $8(30.7 \%)$ cases. This was followed by $5(19.2 \%)$ cases with exon 6 mutation and $4(15.3 \%)$ cases with exon 8 mutation. None of the cases revealed exon 7 mutation. A considerable number 9 (34.6\%) of BCC displayed dual exon mutation. Dual mutations of exon 6 \& 8 were seen in $6(23 \%)$ cases. Exon 5 \& 7 mutation was noted in $2(7.6 \%)$ cases followed by a single (3.8\%) case with exon $6 \& 7$ mutation. The highest number $12(46.1 \%)$ of single and dual exon mutations was recorded in nodular subtype of BCC. Conclusion: The current study confirms the expression of p53 gene mutation in BCC in colored population. Majority of the single mutations were observed in exon 5 . Dual exon mutation was the most notable finding of this study. The highest number of single and dual exon mutations was recorded in nodular form of BCC.

Key words: $\quad$ Basal Cell Carcinoma (BCC), BCC Subtypes, p53 Exon Mutation in BCC, p53 Dual EXon Mutations in BCC.

Article Citation: Jaffar N, Kehar SI, Zaman A, Akram S, Abbas K. Spectrum of Tp53 gene mutation in basal cell carcinoma and its morphological subtypes in people of color. Professional Med J 2019; 26(10):1783-1788.

DOI: $10.29309 / T P M J / 2019.26 .10 .4141$

\section{INTRODUCTION}

Among cutaneous malignancies basal cell carcinoma (BCC) is the most common form worldwide. It also represents the most common malignancy in white population. Incidence of BCC has increased annually in different parts of the world including USA, Australia, Europe and Canada. The highest incidence of BCC is reported in Queensland, Australia. ${ }^{1}$ Presence of $\mathrm{BCC}$ in non-white population has also been well documented. Most of the cases of BCC in colored population (Asians) are reported to clinics as late presentation. An increased morbidity and mortality was noticed in people of color (Asians) when compared to whites. ${ }^{2}$

Available literature suggests that p53 tumor suppressor gene mutation is an important factor in the carcinogenesis of BCC. TP53 gene also famously known as guardian of genome plays a central role in the maintenance of normal cellular growth and differentiation. It regulates the cell cycle and also maintains chromosomal stability by encoding a phosphoprotein. It prevents the proliferation of cells with damaged DNA from entering into the cell cycle. Alteration in the normal 
signaling pathway of the gene promotes the neoplastic process. ${ }^{3}$ The coding sequence of p53 gene comprised of exon 2 to exon 11. However, exons 5-8 constitute the DNA binding domain. It is in this domain that majority of mutations occur. ${ }^{4}$

The frequent loss of p53 gene function in a considerable number of human cancers has led to the development of p53 based cancer therapies. Therefore currently p53 based tumor vaccines are also under trial. Identification of p53 gene mutations is significant as the advent of anti p53 cancer therapy has brought forward a new and promising outlook in the treatment of the patients. $^{5}$

The pattern of exons specific p53 mutations remains undetected in our population. Detection of specific exon mutations may also prove beneficial in targeted molecular therapeutics for the treatment of BCC. The present study was designed to observe the expression and spectrum of exon specific Tp53 gene mutations in basal cell carcinoma and their morphological subtypes in our population.

\section{MATERIALS AND METHODS}

A retrospective cross sectional study was performed over a five-year period from January 2012 to December 2016 at Department of Pathology, Basic Medical Sciences Institute, Jinnah Post Graduate Medical Center Karachi, Pakistan. The study was approved by the Ethical Review Board of BMSI, JPMC. A total of $86 \mathrm{BCC}$ cases were reported at BMSI, during the above mentioned period. Sample size was calculated using open EPI software. Convenient sampling technique was used. The sample size obtained was 32 . The tissue samples were paraffin embedded blocks. Histological sections were stained with hematoxylin and eosin for the morphological review. Polymerase Chain Reaction technique was performed to note the expression of p53 gene mutations in exons 5-8. Sebaceous carcinoma and malignant melanoma were used as positive controls and normal skin was used as negative control. Statistical analysis was performed by SPSS version 22.0. BCC subtypes and p53 exon mutations were summarized in terms of frequencies and percentages.

\section{DNA Extraction}

The DNA purification from tissue was carried out by using Epicenter Kit (MCD 85201) and the protocol was followed accordingly as provided in the extraction kit.

\section{Polymerase Chain Reaction}

Polymerase chain reaction (PCR) was performed by conventional methods. The master mix was prepared in a tube containing $200 \mu \mathrm{l}$ of reaction made up of the following components: $10 \mathrm{X}$ PCR buffer and $1.5 \mathrm{Mm} \mathrm{MgCl2.,} \mathrm{20pmol} \mathrm{of} \mathrm{each}$ primers (Forward and reverse) $500 \mu \mathrm{m}$ of four deoxynucleotides mixture, $2.5 \mathrm{U}$ of Taq DNA polymerase (Promega), The thermal cycler (Master Gradient PCR system, Eppendorf AG, Germany) was programmed to incubate the sample for 5 minutes for $95^{\circ} \mathrm{C}$ followed by 45 cycles consisting of $94^{\circ} \mathrm{C}$ for 45 seconds, $55^{\circ} \mathrm{C}$ for 50 seconds and $72^{\circ} \mathrm{C}$ for one minutes, 30 seconds respectively with final extension for 8 minutes at $72^{\circ} \mathrm{C}$. The PCR amplified products were identified by gel electrophoresis. The amplified products were compared with 100-bp DNA ladder (Gibco BRL, Life Technologies). Mutation was detected and compared with control positive and negative cases.

The amplified product was identified on agarose and bands were identified by using the DNA ladder (M) of $100 \mathrm{bp}$. The DNA mutation was noted at 260-bp of Exon 5, a 160-bp of Exon 6, a 180- bp of Exon7, and a 230 bp of Exon 8, of p53 gene and these positive and negative subjects were compared with positive and negative controls.

\section{RESULTS}

A total of 32 basal cell carcinoma cases were analyzed for p53 gene mutation. Out of these 26 $(81.2 \%)$ displayed p53 exon mutations. Different patterns of exon mutations were observed. Single as well as dual exon mutations were recorded (Table-l). Dual exon mutation was observed in 9 $(34.6 \%)$ cases. Table-II describes the individual exon mutations in various morphological forms of BCC. Majority of mutations i.e. 12 (46.1\%) were noted in nodular variant. Amongst mixed 
morphological variants of BCC, 3 (11.5\%) alterations were noted in combined nodular and pigmented variant. Figures-1, 2, and 3 depict exon specific p53 mutation in 32 BCC cases. Mutant p53 is represented by wide white transverse bars in the graph.

\begin{tabular}{|c|c|c|}
\hline P53 Exon Mutations & No. of Mutations & Percentage \\
\hline \multicolumn{3}{|c|}{ Single Exon Mutation } \\
\hline Exon 5 & 8 & $30.7 \%$ \\
\hline Exon 7 & - & - \\
\hline Exon 8 & 4 & $15.3 \%$ \\
\hline Total no. of single mutations & 17 & $65.3 \%$ \\
\hline Exon 5 \& 7 & 2 & $7.6 \%$ \\
\hline Exon $6 \& 7$ & 1 & $3.8 \%$ \\
\hline Exon $6 \& 8$ & 6 & $23 \%$ \\
\hline Total no. of Dual Mutations & 9 & $34.6 \%$ \\
\hline Total no. of BCC cases with p53 mutation & 26 & $100 \%$ \\
\hline
\end{tabular}

Table-I. Pattern of p53 exon mutations in 26 positive cases of BCC $(n=26)$

\begin{tabular}{|c|c|c|c|c|c|c|c|c|}
\hline $\mathrm{BCC}$ & Exon & Exon & Exon & Exon & Exon & Exon & Exon & Total no. of \\
\hline Morphology & 5 & 6 & 7 & 8 & $5 \& 7$ & $6 \& 7$ & $6 \& 8$ & $\begin{array}{c}\text { exon } \\
\text { mutations }\end{array}$ \\
\hline Nodular & 1 (3.8\%) & 2 (7.6\%) & - & $\begin{array}{c}3 \\
(11.5 \%)\end{array}$ & $\begin{array}{c}2 \\
(7.6 \%)\end{array}$ & - & $\begin{array}{c}4 \\
(15.3 \%)\end{array}$ & $\begin{array}{c}12 \\
(46.1 \%)\end{array}$ \\
\hline Pigmented & $1(3.8 \%)$ & - & - & - & - & - & - & $\begin{array}{c}1 \\
(3.8 \%)\end{array}$ \\
\hline Adenoid & 1 (3.8\%) & - & - & - & - & - & - & $\begin{array}{c}1 \\
(3.8 \%)\end{array}$ \\
\hline Solid & - & - & - & - & - & - & - & 0 \\
\hline Basosquamous & $1(3.8 \%)$ & - & - & - & - & - & - & $\begin{array}{c}1 \\
(3.8 \%)\end{array}$ \\
\hline Morphoeiform & - & - & - & - & - & - & - & 0 \\
\hline Nodular \& pigmented & $1(3.8 \%)$ & 1 (3.8\%) & - & - & - & - & $\begin{array}{c}1 \\
(3.8 \%)\end{array}$ & $\begin{array}{c}3 \\
(11.5 \%)\end{array}$ \\
\hline Nodular \& solid & - & $1(3.8 \%)$ & - & $1(3.8 \%)$ & - & - & - & $\begin{array}{c}2 \\
(7.6 \%)\end{array}$ \\
\hline Nodular \& Adenoid & - & - & - & - & - & $1(3.8 \%)$ & - & $\begin{array}{c}1 \\
(3.8 \%)\end{array}$ \\
\hline $\begin{array}{l}\text { Nodular \& } \\
\text { Morphoeiform }\end{array}$ & - & - & - & - & - & - & - & 0 \\
\hline Solid \& Adenoid & - & - & - & - & - & - & $\begin{array}{c}1 \\
(3.8 \%)\end{array}$ & $\begin{array}{c}1 \\
(3.8 \%)\end{array}$ \\
\hline $\begin{array}{l}\text { BCC with focal } \\
\text { squamous diff }\end{array}$ & 1 (3.8\%) & 1 (3.8\%) & - & - & - & - & - & $\begin{array}{c}2 \\
(7.6 \%)\end{array}$ \\
\hline $\begin{array}{l}\text { BCC with >2 } \\
\text { morphologies }\end{array}$ & 2 (7.6\%) & - & - & - & - & - & - & $\begin{array}{c}2 \\
(7.6 \%)\end{array}$ \\
\hline Total & 8 (30.7\%) & $\begin{array}{c}5 \\
(19.2 \%)\end{array}$ & 0 & $\begin{array}{c}4 \\
(15.3 \%)\end{array}$ & $\begin{array}{c}2 \\
(7.6 \%)\end{array}$ & 1 (3.8\%) & $\begin{array}{c}6 \\
(23 \%)\end{array}$ & $\begin{array}{c}26 \\
(100 \%)\end{array}$ \\
\hline
\end{tabular}

Table-II. Distribution of p53 exon mutation in various morphological forms of BCC $(n=26)$ 


\section{PCR gel-s for p53 Exon 5-8 mutations in Basal cell carcinoma}

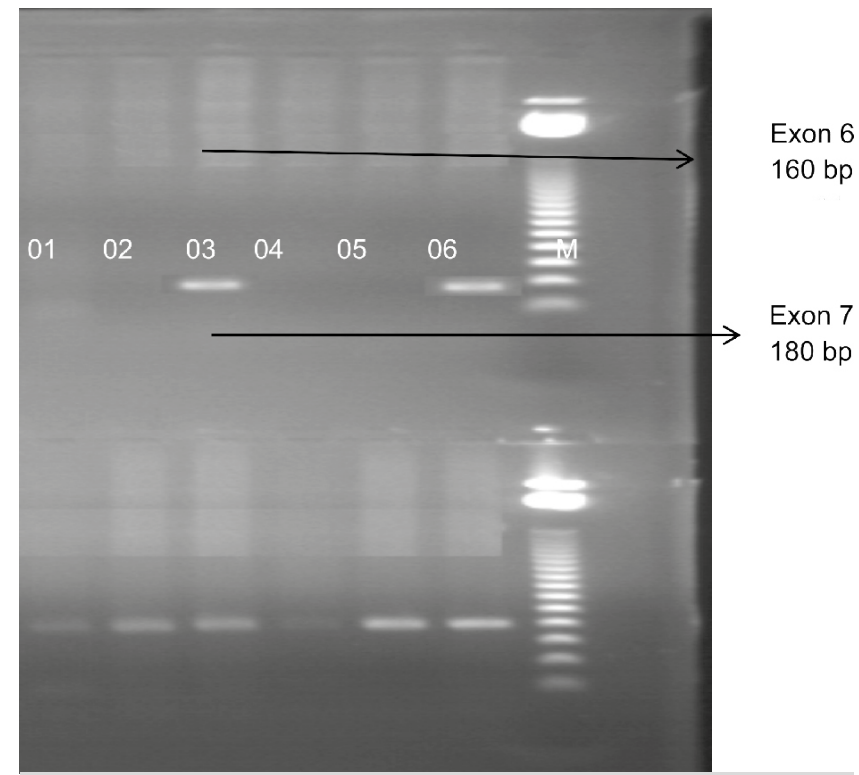

Figure-1. In mix 1 including cases 1-6. Mutant p53 shown as wide white transverse lines by conventional Polymerase chain reaction methods against the ladder

(M) of $100 \mathrm{bp}$ DNA. Positive cases showing bands of mutant exon 6 visualized at 160 bp and and exon 7 at $180 \mathrm{bp}$.

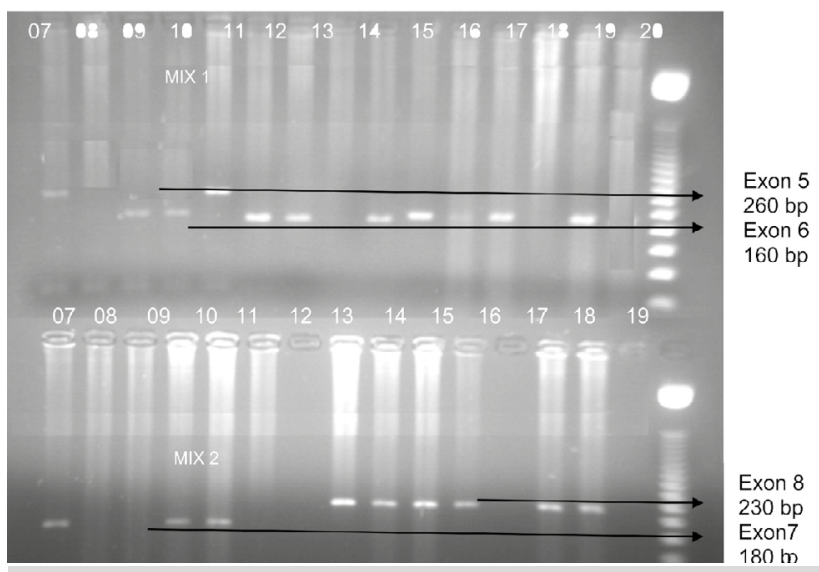

Figure-2. Batch 2 including cases 7-21. Mutant p53 shown as wide white transverse lines by conventional polymerase chain reaction methods against the ladder (M) of 100 bp DNA. Positive cases showing bands of mutant exon 5 visualized at $260 \mathrm{bp}$, exon 6 at $160 \mathrm{bp}$, exon 7 at $180 \mathrm{bp}$ and exon 8 at $230 \mathrm{bp}$.

\section{DISCUSSION}

Present study investigated exon specific p53 mutation in BCC cases presented to JPMC Karachi. Studies analyzing p53 mutations in BCC have been performed in the West but to the best of our knowledge, we did not find similar studies conducted in the metropolis of Karachi.

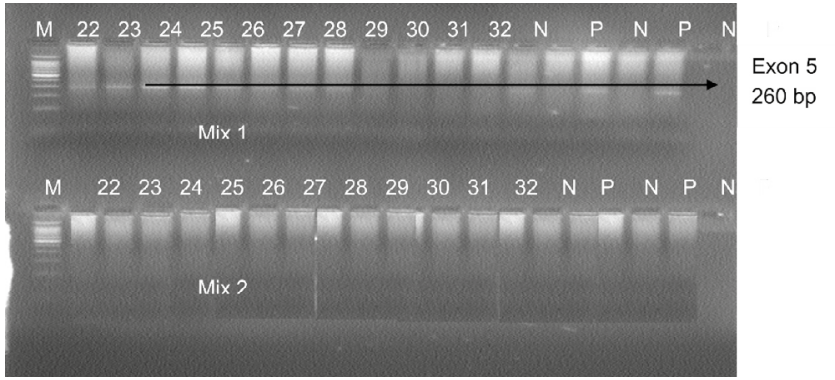

Figure-3. Batch 3 including cases 22-32. Mutant p53 shown as wide white transverse lines by conventional polymerase chain reaction methods against the ladder (M) of 100 bp DNA. Positive cases showing bands of mutant exon 5 visualized at $260 \mathrm{bp}$. Positive and negative controls are shown at the end. Sebaceous carcinoma and malignant melanoma were used as positive controls and normal skin was used as negative control.

Out of 32 diagnosed basal cell carcinoma cases $26(81.2 \%)$ revealed p53 mutations. This finding is in accordance with a study by Bukhari et al. which reported $70 \%$ of p53 alterations. ${ }^{6} \mathrm{~A}$ lower frequency of mutation i.e. $47.2 \%$ was noted by Bolshakov et al. ${ }^{7}$ Kanjilal et al. in a database from various laboratories in United States reported a variable range of $12-56 \%$ p53 mutations. ${ }^{8}$ This discordance in results may be due to difference in sample size and variable study durations.

Moreover 6 (18.7\%) cases did not express p53 exon mutations in the current study. This finding endorses the fact that multiple factors are involved in carcinogenesis of BCC. The role of PTCH and SMOH gene mutations has been well documented. ${ }^{9}$ Mutations of exons other than exons $5-8$ also exist. In a study $14.2 \%$ exon 4 mutations and $28.5 \%$ exon 9 mutations were reported. ${ }^{10}$

In the present study PCR analysis was performed on the four exons i.e. 5-8 of the DNA binding domains of p53. Exon 5 mutations were noted in majority i.e. $8(30.7 \%)$ of cases (Table-I). Kubo et al. elaborated the finding of $100 \%$ mutations in the same. Rady et al. on the contrary reported no mutation in exons 5 . Current study showed $19.2 \%$ and $15.3 \%$ exon 6 and exon 8 mutations respectively. Rady et al. reported $28.5 \%$ exon 8 mutations however none of the studies specifically mentioned about exon 6 mutation. In 
our study none of the cases revealed individual exon 7 mutations, a finding supported by Kubo et al. On the contrary, $71.4 \%$ exon 7 mutations was reported by Rady et al. ${ }^{10,11}$ These variable results in available literature may be attributed to skin color, geographical, environmental and genetic differences.

Presence of dual exon mutation was a distinguished feature of the present study (Table-I). We observed combined exon 7 and exon 5 mutations in $2(7.6 \%)$ cases and exon 7 and exon 6 dual alterations in 1 (3.8\%) case respectively. Furthermore, majority of BCC with nodular morphology (Table-II) showed exon 8 mutations either singly $(11.5 \%)$ or in combination with exon 6 in $15.3 \%$ cases. In $3.8 \%$ each of mixed variants i.e. in combinations of nodular and pigmented as well as solid and adenoid, similar pair of exon 6 and exon 8 mutations was expressed. Literature search was not helpful in finding a comparable study with more than one mutation. Ziegler et al. however, has reported multiple exon mutations in BCC. The reason of more than one exon mutations could be repeated sun exposure rendering the patients prone to secondary and tertiary mutations. Effect of sunlight on mutation hotspots may produce more than one mutation in BCC. ${ }^{12}$ Identification of multiple exon mutations in BCC provides a platform for further research.

BCC usually has an indolent course but some of the cases behave aggressively and occasionally present withmetastasis. Several studies in literature reported association of tumor aggressiveness and progression with p53 mutations in a wide variety of cancers. Ohgaki et al. and Ito et al. found a higher frequency of p53 mutations in aggressive and high grades tumors of brain, and thyroid neoplasms respectively. ${ }^{13,14}$ De Rosa et al. in their study identified p53 expression in aggressive BCC subtypes. ${ }^{15}$ Mixed variant of BCC has been reported to have a tendency to recur and show an aggressive clinical behavior. ${ }^{16}$ This fact is supported by the presence of 11 (42.3\%) mutations in mixed pattern BCC in our study. Furthermore, nodular variant of BCC is generally considered a non-aggressive entity. ${ }^{17}$ However, in our study (Table-I) a considerable number of this variant i.e. 12 (46.1\%) expressed single as well as dual p53 exon mutations. This result signifies the identification of specific exon mutations in BCC to understand its clinical behavior. Moreover, it can also be concluded that certain non-aggressive histological variants of BCC can also progress to aggressive form by acquiring new p53 gene mutations after prolong exposure to Ultraviolet light from sun.

Lately p53 based anticancer therapies have been under clinical trials. Gene therapies specifically targeted for p53 mutations were initially conducted in $1996 .{ }^{18}$ In China Gendicine and in US Advexin were the p53 gene therapies were being utilized in multiple clinical trials. ${ }^{19}$ Identifying specific p53 mutations can be a useful tool in designing targeted therapy for BCC patients among colored population.

Limitation of this study was loss of follow up of the patients.

\section{CONCLUSION}

The current study confirms the expression of TP53 gene in BCC in colored population. Majority of the single mutations were observed in exon 5. Dual exon mutation was the most interesting finding of this study. Exon 6 and exon 8 was the most frequently observed combination in individual as well as mixed variants of BCC. The highest number of single and dual exon mutations was recorded in nodular form of BCC in our population. Specific gene mutations are helpful in understanding the clinical behavior of the tumor. The dual mutations probably represent multiple level carcinogenesis in BCC which needs further exploration and research.

\section{Copyright $(15$ Mar, 2019.}

\section{REFERENCES}

1. Dessinioti C, Antoniou C, Katsambas A, Stratigos AJ. Basal cell carcinoma: What's new under the sun. Photochem Photobiol. 2010; 86:481-91.

2. Agbai ON, Buster K, Sanchez M, Hernandez C, Kundu RV, Chiu M, et al. Skin cancer and photoprotection in people of color: A review and recommendations for physicians and the public. J Am Acad Dermatol. 2014; 70(4):748-62. 
3. de Zwaan SE, Haass NK. Genetics of basal cell carcinoma. Australas J Dermatol. 2010; 51:81-92.

4. Vegran F, Rebucci M, Chevrier S, Cadouot M, Boidot R, Lizard-Nacol S. Only missense mutations affecting the DNA binding domain of p53 influence outcomes in patients with breast carcinoma. PloS one. 2013 Jan 24; 8(1):e55103.

5. Levesque AA, Eastman A. p53-based cancer therapies: Is defective p53 the Achilles heel of the tumor? Carcinogenesis. 2006 Nov 4; 28(1):13-20.

6. Bukhari $\mathrm{MH}$, Niazi S, Khaleel ME, Sharif MA, Ghani $\mathrm{R}$, Mehmood MT, et al. Elevated frequency of p53 genetic mutations and AgNOR values in squamous cell carcinoma. J Cutan Pathol 2009; 36:220-8.

7. Bolshakov S, Walker CM, Strom SS, Selvan MS, Clayman GL, El-Naggar A, et al. P53 mutations in human aggressive and nonaggressive basal and squamous cell carcinoma. Clin Cancer Res 2003; 9:228-234.

8. Kanjilal S, Strom SS, Clayman GL, Weber RS, El-Naggar AK, Kapur V, et al. P53 mutations in nonmelanoma skin cancer of the head and neck: Molecular evidence for field cancerization. Cancer Res 1995; 55:3604-3609.

9. Reifenberger J, Wolter $M$, Knobbe CB, Köhler B, Schönicke A, Scharwächter C, Kumar K, Blaschke B, Ruzicka T, Reifenberger G. Somatic mutations in the PTCH, SMOH, SUFUH and TP53 genes in sporadic basal cell carcinomas. British Journal of Dermatology. 2005 Jan 1; 152(1):43-51.

10. Kubo $\mathrm{Y}$, Urano $\mathrm{Y}$, Yoshimoto $\mathrm{K}$, Iwahana H Ful K, Arase $S$, Itakura $M$. p53 gene mutations in human skin cancers and precancerous lesions: Comparison with immunohistochemical analysis. J Invest Dermatol 1994; 102:440-444.
11. Rady P, Scinicariello F, Wagner RF, Tyring SK. P53 mutations in basal cell carcinomas. Cancer Res 1992; 52:3804-3806.

12. Ziegler A, Leffell DJ, Kunala S, Sharma HW, Gailani M, Simon JA, et al. Mutation hotspots due to sunlight in the p53 gene of nonmelanoma skin cancers. Proc Nad Acad Sci USA 1993; 90:4216-20.

13. Ohgaki $\mathrm{H}$, Eibl $\mathrm{RH}$, Wiestler OD, Yasargil MG, Newcomb EW, Kleihues P. p53 mutations in nonastrocytic human brain tumors. Cancer Res 1991; 51:6202-5.

14. Ito T, Seyama T, Mizuno T, Tsuyama N, Hayashi T, Hayashi $Y$, et al. Unique association of p53 mutations with undifferentiated but not with differentiated carcinomas of the thyroid gland. Cancer Res 1992; 52:1369-71.

15. De Rosa GStaibano SBarra $E$ et al. p53 protein in aggressive and non-aggressive basal cell carcinoma. J Cutan Pathol. 1993; 20429- 434.

16. Huang CC. Cutaneous carcinoma with mixed histology. Southern medical journal. 2005 Jul 1;98(7):680-1.

17. Crowson AN. Basal cell carcinoma: Biology, morphology and clinical implications. Mod Pathol 2006; 19:127-S147.

18. Suzuki $K$, Matsubara $H$. Recent advances in p53 research and cancer treatment. J Biomed Biotechnol. 2011; 2011:978312.

19. Lane DP, Cheok CF and Lain S. p53 based cancer therapy. Cold Spring Harb Perspect Biol 2010; 2:1-23.

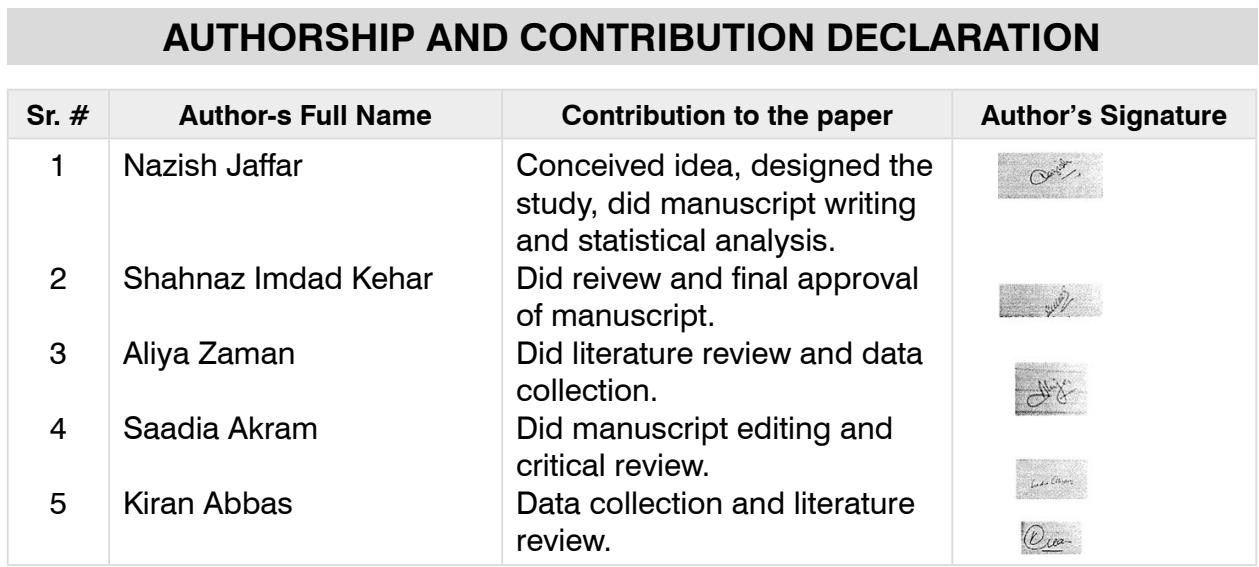

